\title{
Closure of a hyperextended system in an orogenic lithospheric pop-up, Western Pyrenees: The role of mantle buttressing and rift structural inheritance
}

Nicolas Saspiturry ${ }^{1}$, Cécile Allanic ${ }^{*}$, Philippe Razin ${ }^{1}$, Benoit Issautier², Thierry Baudin², Eric Lasseur $^{2}$, Olivier Serrano ${ }^{2}$, Sophie Leleu ${ }^{1}$

${ }^{1}$ ENSEGID - Institut polytechnique de Bordeaux - France

2 Bureau de Recherches Géologiques et Minières (BRGM) - France

The Early Cretaceous hyperextended Mauléon rift is localized in the north-western Pyrenean orogen. We infer the Tertiary evolution of the Mauléon basin through the restoration of a 153 km-long crustal-scale balanced cross-section of the Pyrenean belt, which documents at least $67 \mathrm{~km} \mathrm{(31 \% )} \mathrm{of} \mathrm{orogenic} \mathrm{shortening} \mathrm{in} \mathrm{the} \mathrm{Western} \mathrm{Pyrenees.} \mathrm{Initial} \mathrm{shortening,}$ accommodated through inversion of inherited crustal structures, led to formation of a pop-up structure, in which the opposite edges underwent similar shortening with different tectonic reactivation styles, localized versus. distributed. Underthrusting of the Iberian margin accommodated further convergence, forming the Axial Zone antiformal stack of crustal nappes within a lithospheric pop-up. Thin-skinned and thick-skinned structures propagated outward

from the heart of this pop-up, a block of strong mantle acting as a buttress inhibiting complete inversion of the Mauléon rift basin.

This work is part of the OROGEN project, cofunded by Total S.A., BRGM and Institut national de sciences de l'Univers (INSU).

Mots-Clés : Lithospheric pop-up, mantle butress, Mauleon hyperextended basin inversion 